\title{
HUBUNGAN PENERANGAN DI TEMPAT KERJA DAN KARAKTERISTIK PEKERJA DENGAN KELUHAN KELELAHAN MATA PADA PENJAHIT BORDIR DI CV.X BANGIL-PASURUAN
}

\author{
Dhita Makhsunah Purwaningtyas \\ Departemen Keselamatan dan Kesehatan Kerja \\ Fakultas Kesehatan Masyarakat, Universitas Airlangga \\ E-mail: dhitamp@gmail.com
}

\begin{abstract}
Improper lighting that is not according to the standards may result in health problems, one of which is eyestrain, a visual disturbance. Eyestrain is one result of improper lighting that is not according to standards. Besides, the characteristics of workers also play a role in the occurrence of eyestrain. The purpose of this study is to determine the relationship between the lighting in a workplace and the characteristics of workers with complaints of eyestrain in embroidery tailors at $C V$ " $X$ " Bangil, Pasuruan. This study is an observational study with a cross-sectional study design. The research population was all embroidery tailors in $C V$ " $X "$ Bangil, Pasuruan, as many as 122 workers. The research sample was taken using the Simple Random Sampling method, and 55 workers were obtained. The data were collected by measuring the workplace lighting using a lux meter measuring instrument. The research instrument used were observation sheets and questionnaires. The data analysis was done using Fisher's Exact Test. The results of lighting measurements indicate that the intensity of illumination both general and local is still below the Standard Value. The poor quality of lighting is indicated by most workers who experienced glare, shadow disturbances, and improper workplace decorations. The results of the statistical test show that the p-value of all variables $>\alpha(0.05)$. There is a significant relationship between the lighting in the workplace and the characteristics of workers with eyestrain. $C V$ " $X$ " needs to schedule maintenance and cleaning for lights, armatures, wall windows, floors and work desks. Besides, it is necessary to increase the intensity of lighting in the workplace.
\end{abstract}

Keywords: Lighting, Worker Characteristics, Eyestrain

\begin{abstract}
ABSTRAK
Penerangan yang tidak sesuai dengan standar dapat menyebabkan gangguan kesehatan salah satunya adalah gangguan kelelahan pada mata. Kelelahan mata merupakan salah satu akibat dari penerangan yang tidak sesuai standar. Selain itu, karakteristik pekerja juga turut berperan dalam terjadinya kelelahan mata tersebut. Tujuan dari penelitian ini adalah untuk mengetahui hubungan penerangan di tempat kerja dan karakteristik pekerja dengan keluhan kelelahan mata pada penjahit bordir di CV "X" Bangil, Pasuruan. Penelitian ini merupakan penelitian observasional dengan desain studi cross-sectional. Populasi penelitian adalah seluruh penjahit bordir di CV " $\mathrm{X}$ " Bangil, Pasuruan sebanyak 122 pekerja. Sampel penelitian diambil dengan metode Simple Random Sampling dan diperoleh 55 pekerja. Data dikumpulkan dengan mengukur pencahayaan menggunakan alat ukur luxmeter. Instrumen penelitian menggunakan lembar observasi dan kuesioner. Analisis data
\end{abstract}


menggunakan uji Uji Fisher's Exact. Hasil pengukuran penerangan menunjukkan bahwa intensitas penerangan baik umum maupun lokal masih di bawah Nilai Standar. Kualitas penerangan ditunjukkan oleh sebagian besar pekerja mengalami gangguan kesilauan, gangguan bayangan dan ketidaksesuaian dekorasi tempat kerja. Hasil uji statistik menunjukkan bahwa nilai p semua variabel $>\alpha(0,05)$. Terdapat hubungan yang signifikan antara penerangan di tempat kerja dan karakteristik pekerja dengan kelelahan mata. CV " $\mathrm{X}$ " perlu untuk membuat jadwal pemeliharaan dan pembersihan lampu, armatur, jendela dinding, lantai dan meja kerja. Selain itu, perlu meningkatkan intensitas penerangan di tempat kerja.

Kata kunci: Penerangan, Karakteristik Pekerja, Kelelahan Mata

\section{PENDAHULUAN}

Lingkungan tempat kerja di dalam suatu industri mempunyai pengaruh yang dramatis terhadap produktivitasnya. Penelitian di lapangan tentang efisiensi tenaga kerja menunjukkan bahwa apabila kenyamanan fisik dan fisiologi tenaga kerja diperbaiki, maka dalam melaksanakan pekerjaannya menjadi lebih efisien, produk yang dihasilkan juga akan meningkat, sehingga bagi perusahaan lebih menguntungkan. Salah satunya yang dapat meningkatkan suasana lingkungan kerja yang nyaman yaitu adalah kualitas dan kuantitas penerangan baik di tempat kerja maupun penerangan seluruh lingkungan kerja yang dapat berpengaruh positif terhadap kesehatan, keselamatan dan kenyamanan bagi tenaga kerja. Karena itu, penerangan yang baik dapat memperbaiki moral kerja, motivasi kerja dan efisiensi hasil produksi ${ }^{1}$. Penerangan di tempat kerja yang kurang memenuhi persyaratan baik kondisi penerangan yang tinggi, rendah, maupun yang menyilaukan akan memperburuk penglihatan, karena jika pencahayaan terlalu besar ataupun kecil, pupil mata harus berusaha menyesuaikan cahaya yang diterima oleh mata. Akibatnya mata harus memicing silau atau berkontraksi secara berlebihan, karena jika pencahayaan lebih besar atau lebih kecil pupil mata harus berusaha menyesuaikan cahaya yang dapat diterima oleh mata. Pupil akan mengecil jika menerima cahaya yang besar. Hal ini merupakan salah satu penyebab mata cepat lelah. Kelelahan mata merupakan gangguan yang dialami mata karena otot-ototnya yang dipaksa bekerja terutama saat harus melihat objek dekat dalam jangka waktu lama. Kelelahan mata disebabkan oleh stres yang terjadi pada fungsi penglihatan. Stres pada otot akomodasi dapat terjadi saat seseorang berupaya untuk melihat objek berukuran kecil dan pada jarak yang dekat dalam waktu yang lama ${ }^{2}$.

Hasil penelitian dari Febriana (2012) menunjukkan penggunaan intensitas penerangan sebesar 49,8 lux dan tertinggi sebesar 223,3 lux pada bagian administrasi di PT. Indonesia Power UBP Semarang mengakibatkan $86,4 \%$ pekerja merasakan kelelahan mata ${ }^{3}$. Selain itu pada penelitian Hikmatyar (2012) menunjukkan bahwa gejala Computer Vision Syndrome (sakit 
kepala, pusing, penglihatan kabur, sakit leher, mata merah, bahkan kelelahan) dirasakan oleh pekerja layout editor di CV "X" Tembalang kota Semarang akibat menggunakan intensitas penerangan sebesar 50 lux dan menimbulkan kesilauan ketika menggunakan intensitas penerangan sebesar 50 lux dan menimbulkan kesilauan ketika menggunakan intensitas penerangan sebesar $2853 \operatorname{lux}^{4}$. Kelelahan mata akibat penggunaan intensitas penerangan yang tidak memadai juga ditemukan di tempat kerja pengrajin Karawo di Kabupaten Gorontalo, menurut Hiola (2000) dari hasil penelitiannya didapatkan bahwa jumlah intensitas penerangan di lingkungan kerja pengrajin ditemukan kurang dari 200 lux dan tertinggi 400 lux yaitu sebanyak $96,80 \%$ pekerja yang mengalami keluhan kelelahan mata ${ }^{5}$.

Industri bordir yang sedang berkembang di daerah Bangil Provinsi Jawa Timur saat ini adalah industri seni kerajinan bordir busana muslim dimana teknik pembuatan hasil produksi melibatkan tenaga manusia. Proses pembuatan seni kerajinan bordir, dibutuhkan kemampuan ketelitian penglihatan dan tingkat ketajaman penglihatan yang tinggi dalam membedakan warna benang dan kerapian hasil jahitan pada kain sebagai media jahit yang digunakannya, selain itu waktu kerja tenaga kerja penjahit seni kerajinan bordir relatif lama yaitu kurang lebih selama 8 jam dalam sehari. Pekerjaan sebagai penjahit seni kerajinan bordir tersebut dilakukan untuk memenuhi kebutuhan hidup sehari-hari.
CV "X" merupakan perusahaan kerajinan seni bordir yang memproduksi pakaian busana muslim berupa baju Taqwa, peci atau penutup kepala pria, dan mukena. Produk yang dihasilkan CV "X" selain menggunakan sentuhan seni bordir tangan (hand made) dan menggunakan seni bordir dengan mesin jahit manual, juga memadukan seni bordir dengan menggunakan mesin bordir komputer sehingga didapatkan hasil seni bordir yang berkualitas.

Proses produksi seni kerajinan bordir di bagian jahitan tersebut dilakukan secara manual. Tenaga kerja secara manual melakukan pekerjaan rutin membuat seni kerajinan bordir yang berkualitas. Banyaknya permintaan konsumen terhadap hasil produksi seni kerajinan bordir yang cukup tinggi, membuat tenaga kerja harus memiliki ketelitian penglihatan dan tingkat ketajaman penglihatan yang tinggi serta waktu yang cukup lama pada pekerja sehingga membutuhkan kondisi penerangan lingkungan kerja sesuai dengan standar tertentu untuk hasil produksi yang lebih optimal. Diketahui bahwa kuantitas dan kualitas penerangan belum cukup memadai karena masih ditemukan adanya kesilauan dan bayangan, arah penyebaran cahaya yang tidak merata, serta penggunaan dekorasi ruang yang kurang tepat. Penerangan yang memadai sangat dibutuhkan agar tenaga kerja khususnya pada bagian penjahit dapat bekerja dengan nyaman dan tidak mengalami kelelahan mata akibat bekerja. Keluhan kelelahan mata yang dialami oleh tenaga kerja, 
diantara-nya mata merah, berair, penurunan ketajaman, penglihatan ganda dan sakit kepala sekitar mata saat melakukan aktivitas menjahit. Keadaan seperti itu sering dirasakan pekerja pada saat mereka sudah bekerja selama 2-3 jam dengan kurun waktu bekerja selama 8 jam setiap harinya. Selain penerangan, karakteristik tenaga kerja seperti usia, masa kerja, lama kerja, kelainan refraksi (penggunaan kacamata), kebiasaan merokok, dan riwayat penyakit juga dapat berpengaruh terhadap kelelahan mata pekerja. Berdasarkan masalah yang terdapat di bagian produksi penjahit CV "X" BangilPasuruan tersebut, maka dilakukan penelitian mengenai apakah ada hubungan antara karakteristik pekerja terhadap keluhan kelelahan mata akibat penerangan di tempat kerja pada penjahit bordir di CV " $\mathrm{X}$ " Bangil-Pasuruan. Penelitian ini memiliki tujuan umum untuk menganalisis hubungan antara penerangan di tempat kerja dan karakteristik pekerja dengan keluhan kelelahan mata akibat pada penjahit bordir di CV "X" Bangil, Pasuruan. Penelitian ini memiliki tujuan khusus yaitu mengukur kuantitas penerangan (intensitas penerangan), mengidentifikasi kualitas penerangan (kesilauan, bayangan, dekorasi ruang), mengidentifikasi karakteristik tenaga kerja meliputi usia, masa kerja, lama kerja, penggunaan kacamata, dan kebiasaan merokok dalam sehari, mempelajari keluhan kelelahan mata tenaga kerja, menganalisis hubungan antara penerangan tempat kerja (kuantitas dan kualitas) dengan keluhan kelelahan mata tenaga kerja, menganalisis hubungan antara karakteristik tenaga kerja dengan keluhan kelelahan mata tenaga kerja di bagian produksi penjahit bordir CV "X" Bangil, Pasuruan.

\section{METODE PENELITIAN}

Penelitian ini termasuk jenis penelitian deskriptif observasional, karena data yang diperoleh tanpa adanya suatu perlakuan terhadap obyek penelitian maupun pada variabel yang akan diteliti yaitu pengukuran intensitas penerangan, kualitas penerangan, karakteristik pekerja dan kelelahan mata pekerja. Berdasarkan cara analisis data, penelitian ini termasuk analitik. Kemudian berdasarkan dimensi waktunya, penelitian ini menggunakan pendekatan cross-sectional karena data yang diteliti dalam satu waktu. Populasi penelitian ini adalah seluruh tenaga kerja penjahit bordir yang bekerja pada bagian produksi CV "X" di BangilPasuruan yaitu berjumlah 122 orang tenaga kerja. Penentuan sampling pada penelitian ini yaitu menggunakan teknik simple random sampling dan diperoleh besar sampel sebanyak 55 orang tenaga kerja. Variabel yang teliti berupa variabel independen (intensitas penerangan, kesilauan, bayangan, arah cahaya dan dekorasi ruangan, umur, masa kerja, lama kerja, kelainan refraksi mata, dan kebiasaan merokok) dan variabel dependen (keluhan kelelahan mata). Pengumpulan data dalam penelitian ini dilakukan dengan observasi dan 
menggunakan kuesioner. Observasi dilakukan untuk mendapatkan data keadaan lingkungan kerja berupa pengukuran intensitas penerangan dengan menggunakan alat Lux meter lutron tipe Lx-103, kesilauan, bayangan, dan dekorasi ruangan. Data yang didapat kemudian dianalisis secara deskriptif untuk melihat adanya hubungan antara variabel penerangan tempat kerja, karakteristik pekerja, dan keluhan kelelahan mata pada pekerja.

\section{HASIL DAN PEMBAHASAN}

\section{Intensitas Penerangan}

Tabel 1. Distribusi Intensitas Penerangan di Bagian Produksi Penjahit Bordir CV "X” Bangil, Pasuruan Tahun 2018

\begin{tabular}{lrrc}
\hline \multicolumn{1}{c}{ Unit } & \multicolumn{2}{c}{ Intensitas } \\
\cline { 2 - 4 } & Penerangan (Lux) & $\begin{array}{c}\text { Standar } \\
\text { Kemenkes } \\
\text { Nomor }\end{array}$ \\
& & Lokal & $\begin{array}{c}70 / 2016 \\
\text { (Lux) }\end{array}$ \\
\hline Ruang Tengah & 100,0 & 38,5 & 200 \\
Ruang Desain & 57,25 & 53,0 & 300 \\
Gedung Seri & 42,0 & 40,5 & 300 \\
Gedung Baju & 39,5 & 36,0 & 300 \\
Gedung Benang & 51,0 & 34,5 & 300 \\
Setrika Uap & 69,25 & 61,25 & 300 \\
Gedung Saku & 24,0 & 33,67 & 300 \\
Gedung Kera & 48,0 & 49,0 & 300 \\
Jahit Belakang & 102,25 & 250,93 & 750 \\
\hline
\end{tabular}

Berdasarkan Tabel 1, dapat diketahui bahwa rerata intensitas penerangan umum dan lokal paling tinggi dimiliki unit jahit belakang dengan intensitas penerangan sebesar 102,25 lux (umum) dan 250,93 lux (lokal). Sedangkan rerata intensitas penerangan umum dan lokal paling rendah dimiliki oleh Gedung Saku dengan intensitas penerangan sebesar 24 lux (umum) dan 33,67 lux (lokal).

\section{Gambaran Karakteristik Tenaga Kerja}

Tabel 2. Distribusi Frekuensi Karakteristik Pekerja di Bagian Produksi Penjahit Bordir CV "X" Bangil, Pasuruan Tahun 2018

\begin{tabular}{|c|c|c|c|}
\hline Karakteristik & & $\mathrm{n}$ & $\%$ \\
\hline \multicolumn{4}{|l|}{ Umur } \\
\hline$<40$ Tahun & & 23 & 41,8 \\
\hline \multirow{2}{*}{$>40$ Tahun } & & 32 & 58,2 \\
\hline & Total & 55 & 100,0 \\
\hline \multicolumn{4}{|l|}{ Masa Kerja } \\
\hline 1-5 Tahun & & 11 & 20,0 \\
\hline 6-10 Tahun & & 21 & 20,0 \\
\hline \multirow[t]{2}{*}{$>10$ Tahun } & & 23 & 60,0 \\
\hline & Total & 55 & 100,0 \\
\hline \multicolumn{4}{|l|}{ Lama Kerja } \\
\hline 4-8 Jam & & 22 & 40,0 \\
\hline \multirow[t]{2}{*}{$>8 \mathrm{Jam}$} & & 33 & 60,0 \\
\hline & Total & 55 & 100,0 \\
\hline \multicolumn{4}{|l|}{ Kelainan Refraksi } \\
\hline Tidak & & 20 & 36,4 \\
\hline \multirow[t]{2}{*}{$\mathrm{Ya}$} & & 35 & 63,6 \\
\hline & Total & 55 & 100,0 \\
\hline \multicolumn{4}{|l|}{ Kebiasaan Merokok } \\
\hline Tidak & & 18 & 32,7 \\
\hline \multirow[t]{2}{*}{$\mathrm{Ya}$} & & 37 & 67,3 \\
\hline & Total & 55 & 100,0 \\
\hline
\end{tabular}

Berdasarkan Tabel 2, dapat diketahui bahwa sebagian besar pekerja di bagian produksi penjahit bordir CV " $\mathrm{X}$ " memiliki umur $>40$ tahun yaitu sebanyak 32 pekerja $(58,2 \%)$, dengan masa kerja > 10 tahun yaitu sebanyak 23 pekerja $(60,0 \%)$, lama kerja > 8 jam yaitu sebanyak 33 pekerja $(60,0 \%)$, pekerja yang memiliki kelainan refraksi yaitu sebanyak 35 pekerja $(63,6 \%)$, dan pekerja yang memiliki kebiasaan merokok yaitu sebanyak 37 pekerja $(67,3 \%)$. 


\section{Gangguan Kesilauan}

Tabel 3. Distribusi Frekuensi Gangguan Kesilauan Pekerja di Bagian Produksi Penjahit Bordir CV " $\mathrm{X}$ " Bangil, Pasuruan Tahun 2018

\begin{tabular}{lcr}
\hline Gangguan Kesilauan & $\mathrm{n}$ & \multicolumn{1}{c}{$\%$} \\
\hline Ada & 34 & 61,8 \\
Tidak Ada & 21 & 38,1 \\
\hline Total & 55 & 100,0 \\
\hline
\end{tabular}

Berdasarkan Tabel 3, dapat diketahui bahwa sebagian besar pekerja di bagian produksi penjahit bordir yaitu sebanyak 34 pekerja $(61,8 \%)$ merasakan adanya gangguan kesilauan di tempat kerja.

\section{Gangguan Bayangan}

Tabel 4. Distribusi Frekuensi Gangguan Bayangan di Bagian Produksi Penjahit Bordir CV "X" Bangil, Pasuruan Tahun 2018

\begin{tabular}{lcr}
\hline Gangguan Bayangan & $\mathrm{n}$ & \multicolumn{1}{c}{$\%$} \\
\hline Ada & 44 & 80,0 \\
Tidak Ada & 11 & 20,0 \\
\hline Total & 55 & 100,0 \\
\hline
\end{tabular}

Berdasarkan Tabel 4, dapat diinformasikan bahwa sebagian besar pekerja di bagian produksi penjahit bordir yang mengalami gangguan bayangan yaitu sebanyak 44 pekerja $(80,0 \%)$.

\section{Dekorasi Ruangan}

Tabel 5. Distribusi Frekuensi Dekorasi Ruangan di Bagian Produksi Penjahit Bordir CV "X” Bangil, Pasuruan Tahun 2018

\begin{tabular}{lcc}
\hline \multicolumn{1}{c}{ Dekorasi Ruangan } & $\mathrm{n}$ & $\%$ \\
\hline Tidak Sesuai & 36 & 65,5 \\
Sesuai & 19 & 34,5 \\
\hline Total & 55 & 100,0 \\
\hline
\end{tabular}

Berdasarkan Tabel 5, dapat diketahui bahwa sebagian besar pekerja di bagian produksi penjahit bordir sebanyak 36 pekerja $(65,5 \%)$ beranggapan bahwa kondisi penerangan tempat kerja tidak sesuai bila berdasarkan keadaan dekorasi ruangan yang berasal dari tata letak meja kerja dan peralatan kerja lainya.

\section{Hubungan Intensitas Penerangan dengan Keluhan Kelelahan Mata}

Tabel 6. Hubungan Intensitas Penerangan dengan Keluhan Kelelahan Mata pada Pekerja di Bagian Produksi Penjahit Bordir CV "X” Bangil, Pasuruan Tahun 2018

\begin{tabular}{|c|c|c|c|c|c|c|}
\hline \multirow[t]{3}{*}{ Intensitas Penerangan } & \multicolumn{4}{|c|}{ Keluhan Kelelahan Mata } & \multicolumn{2}{|c|}{ Jumlah } \\
\hline & & & & & & \\
\hline & $\mathrm{n}$ & $\%$ & $\mathrm{n}$ & $\%$ & $\mathrm{n}$ & $\%$ \\
\hline Sesuai NAB & 0 & 0,0 & 0 & 0,0 & 0 & 0,0 \\
\hline Tidak Sesuai NAB & 9 & 16,4 & 46 & 83,6 & 55 & 100,0 \\
\hline Jumlah & 9 & 16,4 & 46 & 83,6 & 55 & 100,0 \\
\hline
\end{tabular}

Berdasarkan Tabel 6, diketahui bahwa sebanyak 46 pekerja $(83,6 \%)$ mengalami keluhan kelelahan kerja di tempat kerja yang memiliki penerangan tidak sesuai dengan standar. Sedangkan sebanyak 9 pekerja $(16,4 \%)$ tidak mengalami keluhan kelelahan mata saat bekerja di tempat kerja yang memiliki penerangan tidak sesuai standar. 
Penerangan pada area produksi di bagian penjahit bordir CV X Bangil-Pasuruan memiliki rerata intensitas penerangan umum dan lokal paling tinggi dimiliki unit jahit belakang dengan intensitas penerangan sebesar 102,25 lux (umum) dan 250,93 lux (lokal). Sedangkan rerata intensitas penerangan paling rendah dimiliki oleh Gedung Saku sebesar 24 lux (umum) dan 33,67 lux (lokal).

Berdasarkan hasil pengukuran intensitas penerangan, maka diketahui bahwa intensitas penerangan baik umum maupun lokal di bagian produksi Penjahit Bordir CV " $\mathrm{X}$ " BangilPasuruan tidak memenuhi standar penerangan yang ditetapkan oleh Permenkes RI. Nomor 70 Tahun 2016 tentang Kesehatan Lingkungan Kerja Industri, dimana peraturan tersebut mengatur standar penerangan khususnya di Industri tekstile ${ }^{6}$. Dalam peraturan tersebut, setiap ruang atau bagian memiliki intensitas penerangan yang berbeda-beda sesuai dengan pekerjaan yang dilakukan di dalamnya.

Uji statistika untuk melihat hubungan antara intensitas penerangan dengan keluhan kelelahan mata pada pekerja tidak dapat diperoleh. Hal tersebut karena pada semua titik pengukuran penerangan hanya memiliki satu kategori yang sama yaitu tidak memenuhi standar NAB. Sehingga tidak terdapat pembanding dalam proses uji statistika. Hasil tabulasi menunjukkan pola sebagian besar pekerja yang mengalami keluhan kelelahan mata adalah pekerja yang bekerja dengan penerangan yang tidak sesuai dengan NAB.

Penerangan di tempat kerja yang kurang memenuhi persyaratan tertentu dapat memperburuk penglihatan, karena apabila penerangan ruang kerja terlalu besar ataupun terlalu kecil, maka menyebabkan pupil mata berupaya keras untuk menyesuaikan cahaya yang diterima mata. Akibatnya, mata harus memicing akibat silau ataupun mata berkontaksi secara berlebihan, karena pencahayaan yang intensitasnya lebih besar atau lebih kecil menyebabkan mata berusaha menyesuaikan cahaya yang dapat diterima oleh mata.

Pupil mata akan mengecil apabila menerima cahaya yang besar. Hal ini merupakan salah satu penyebab mata menjadi cepat lelah ${ }^{7}$. Grandjean (1998) dalam Tarwaka (2015) menyebutkan gangguan akibat penerangan yang kurang memenuhi syarat meliputi berkurangnya daya dan efisiensi kerja akibat kelelahan mata, kelelahan mental, keluhan pegal di daerah mata dan sakit kepala di sekitar mata serta kerusakan indera mata ${ }^{8,9}$. 


\section{Hubungan Gangguan Kesilauan dengan Keluhan Kelelahan Mata}

Tabel 7. Hubungan Gangguan Kesilauan dengan Keluhan Kelelahan Mata pada Pekerja di Bagian Produksi Penjahit Bordir CV "X” Bangil, Pasuruan Tahun 2018

\begin{tabular}{|c|c|c|c|c|c|c|}
\hline \multirow[t]{3}{*}{ Gangguan Kesilauan } & \multicolumn{4}{|c|}{ Keluhan Kelelahan Mata } & \multicolumn{2}{|c|}{ Jumlah } \\
\hline & & & & & & \\
\hline & $\mathrm{n}$ & $\%$ & $\mathrm{n}$ & $\%$ & $\mathrm{n}$ & $\%$ \\
\hline Tidak Silau & 7 & 12,7 & 14 & 25,5 & 21 & 100,0 \\
\hline Silau & 2 & 3,6 & 32 & 58,2 & 34 & 100,0 \\
\hline Jumlah & 9 & 16,4 & 46 & 83,6 & 55 & 100,0 \\
\hline
\end{tabular}

Berdasarkan Tabel 7, diketahui bahwa sebanyak 32 pekerja $(58,2 \%)$ mengalami gangguan kesilauan dan keluhan kelelahan mata. Hasil uji statistika fisher exact menunjukkan nilai kontingensi sebesar 0,339. Hubungan gangguan kesilauan dengan keluhan kelelahan mata memiliki hubungan yang cukup kuat. Hal tersebut dapat disimpulkan bahwa gangguan kesilauan di tempat kerja yang dirasakan pekerja berhubungan dengan keluhan kelelahan mata yang dirasakan pekerja.

Gangguan kesilauan sering kali dianggap sebagai penyebab dari rendahnya kualitas dan produktivitas karena dapat menyebabkan turunnya kemampuan melihat, tidak nyaman dan kelelahan mata. Kesilauan disebabkan cahaya yang berlebihan, baik yang berasal dari sumber cahaya atau hasil pantulan ke arah mata seseorang. Adapun penyebabnya adalah terlalu banyaknya cahaya yang masuk secara langsung ke dalam mata yang menyebabkan kehilangan sebagian penglihatan seseorang untuk dapat melihat dengan jelas. Seseorang yang dalam bekerja menghadap sumber secara langsung dalam waktu cukup lama dapat menyebabkan rasa ketidaknyamanan pada mata (discomfort glare).

Selain itu, kesilauan dapat disebabkan oleh pantulan cahaya yang terlalu terang yang mengenai mata. Pantulan cahaya tersebut berasal dari permukaan benda yang mengkilap yang berada dalam medan pengelihatan ${ }^{10}$.

\section{Hubungan Gangguan Bayangan dengan Keluhan Kelelahan Mata}

Tabel 8. Hubungan Gangguan Bayangan dengan Keluhan Kelelahan Mata pada Pekerja di Bagian Produksi Penjahit Bordir CV "X” Bangil, Pasuruan Tahun 2018

\begin{tabular}{|c|c|c|c|c|c|c|}
\hline \multirow{3}{*}{ Gangguan Bayangan } & \multicolumn{4}{|c|}{ Keluhan Kelelahan Mata } & \multirow{2}{*}{\multicolumn{2}{|c|}{ Jumlah }} \\
\hline & \multicolumn{2}{|c|}{ Tidak Ada } & \multicolumn{2}{|c|}{ Ada } & & \\
\hline & $\mathrm{n}$ & $\%$ & $\mathrm{n}$ & $\%$ & $\mathrm{n}$ & $\%$ \\
\hline Tidak Ada & 5 & 9,1 & 6 & 10,9 & 11 & 100,0 \\
\hline Ada & 4 & 7,3 & 40 & 72,7 & 44 & 100,0 \\
\hline Jumlah & 9 & 16,4 & 46 & 83,6 & 55 & 100,0 \\
\hline
\end{tabular}


Berdasarkan Tabel 8, diketahui bahwa sebanyak 40 pekerja $(72,7 \%)$ mengalami gangguan bayangan dan keluhan kelelahan mata. Hasil uji statistika fisher exact yang telah dilakukan menunjukkan nilai kontingensi sebesar 0,366. Hubungan gangguan bayangan dengan keluhan kelelahan mata memiliki hubungan yang cukup kuat. Hal tersebut dapat disimpulkan bahwa gangguan bayangan di tempat kerja yang dirasakan pekerja berhubungan dengan keluhan kelelahan mata yang dirasakan pekerja.

Pekerja yang mengalami gangguan bayangan menyatakan bahwa penyebab gangguan berasal dari dekorasi ruangan antara lain peralatan kerja pengaturan tata letak posisi meja kerja. bayangan umumnya tidak dikehendaki oleh seseorang yang sedang melakukan pekerjaan. Untuk menghindari terjadinya bayangan, penerangan di tempat kerja diusahakan agar menyebar secara merata.

Penerangan setempat diusahakan agar tidak digunakan di tempat kerja karena sistem penerangan ini sering menimbulkan bayangan yang mengganggu kecuali bila penerangan umum di tempat kerja tersebut cukup. Gangguan bayangan yang dialami pekerja dapat menyulitkan mereka untuk bekerja, karena mata harus menyesuaikan diri dengan lingkungan. Bayangan yang gelap pada permukaan kerja merupakan sumber kualitas kerja yang jelek, menyebabkan sakit mata dan kelelahan mata ${ }^{1}$.

\section{Hubungan Dekorasi Ruangan dengan Keluhan Kelelahan Mata}

Tabel 9. Hubungan Dekorasi Ruangan dengan Keluhan Kelelahan Mata pada Pekerja di Bagian Produksi Penjahit Bordir CV "X” Bangil, Pasuruan Tahun 2018

\begin{tabular}{ccccccc}
\hline Dekorasi Ruangan & \multicolumn{3}{c}{ Keluhan Kelelahan Mata } & \multicolumn{3}{c}{ Jumlah } \\
\cline { 2 - 6 } & \multicolumn{2}{c}{ Tidak Ada } & \multicolumn{2}{c}{ Ada } & & $\mathrm{n}$ \\
\cline { 2 - 6 } & $\mathrm{n}$ & $\%$ & $\mathrm{n}$ & $\%$ & $\%$ \\
\hline Sesuai & 9 & 16,4 & 10 & 18,2 & 19 & 100 \\
Tidak Sesuai & 0 & 0,0 & 36 & 65,5 & 36 & 100 \\
\hline Jumlah & 9 & 16,4 & 9 & 16,4 & 55 & 100 \\
\hline
\end{tabular}

Berdasarkan Tabel 9, dapat diketahui bahwa sebanyak 36 pekerja $(65,5 \%)$ menganggap bahwa dekorasi ruangan tidak sesuai sehingga intensitas dan kualitas penerangan di dalam ruangan menjadi buruk, hal tersebut mengakibatkan pekerja mengalami keluhan kelelahan mata. Hasil uji fisher exact menunjukkan nilai kontingensi sebesar 0,520. Hubungan kesesuaian dekorasi ruangan dengan keluhan kelelahan mata adalah memiliki hubungan yang kuat.

Cahaya penerangan mempunyai efek penting terhadap warna, karena dengan adanya warna dapat memengaruhi kualitas penerangan. Efek yang dihasilkan dari penerangan disebut dengan nilai refleksi atau nilai cahaya. Nilai penerangan sangat penting karena akan menghasilkan refleksi atau pantulan dari 
permukaan langit-langit, dinding, mesin dan lantai yang menjadikan sumber cahaya kedua.

Dengan adanya jenis warna dan pemantulan yang tepat, maka permukaan yang ada pada area kerja dapat memaksimalkan penerangan sehingga dapat mengurangi terjadinya bayang- bayang. Kontras warna yang ditimbulkan semakin kecil dan dapat menciptakan kondisi kerja yang nyaman. Sebaliknya kontras warna yang ditimbulkan semakin besar dapat mempercepat timbulnya kelelahan visual atau kelelahan mata ${ }^{1}$.

\section{Hubungan Umur Pekerja dengan Keluhan Kelelahan Mata}

Tabel 10. Hubungan Umur Pekerja dengan Keluhan Kelelahan Mata pada Pekerja di Bagian Produksi Penjahit Bordir CV "X” Bangil, Pasuruan Tahun 2018

\begin{tabular}{|c|c|c|c|c|c|c|}
\hline \multirow[t]{3}{*}{ Umur Pekerja } & \multicolumn{4}{|c|}{ Keluhan Kelelahan Mata } & \multicolumn{2}{|c|}{ Jumlah } \\
\hline & & & & & & \\
\hline & $\mathrm{n}$ & $\%$ & $\mathrm{n}$ & $\%$ & $\mathrm{n}$ & $\%$ \\
\hline$\leq 40$ Tahun & 8 & 14,5 & 14 & 25,5 & 22 & 100,0 \\
\hline > 40 Tahun & 1 & 1,8 & 32 & 58,2 & 33 & 100,0 \\
\hline Jumlah & 9 & 16.4 & 46 & 836 & 55 & 1000 \\
\hline
\end{tabular}

Berdasarkan Tabel 10, diketahui sebanyak 32 pekerja $(58,2 \%)$ dengan usia $>40$ mengalami kelelahan mata. Hasil uji statistika menunjukkan nilai kontingensi sebesar 0,404, yang artinya menunjukkan ada hubungan cukup kuat antara umur dengan keluhan kelelahan mata. Dapat disimpulkan semakin tua usia pekerja semakin tinggi pula risiko terjadinya kelelahan mata.

Umur dapat memiliki hubungan dengan adanya keluhan kelelahan mata. Menurut Tarwaka (2014) semakin bertambahnya usia pekerja maka kekuatan otot akan turun sebesar $25 \%$, dan saat usia melebihi 60 tahun kemampuan kerja fisik akan menurun sebesar $50 \%$ dari kemampuan saat berusia 25 tahun. Semakin bertambahnya usia akan diikuti menurunnya kemampuan fungsi pendengaran, penglihatan, sensorik dalam membuat keputusan, dan kemampuan mengingat jangka pendek. Umur merupakan hal yang harus dipertimbangkan saat akan memberikan pekerjaan yang tepat pada seseorang ${ }^{9}$.

\section{Hubungan Masa Kerja Pekerja dengan Keluhan Kelelahan Mata}

Tabel 11. Hubungan Masa Kerja Pekerja dengan Keluhan Kelelahan Mata pada Pekerja di Bagian Produksi Penjahit Bordir CV "X” Bangil, Pasuruan Tahun 2018

\begin{tabular}{|c|c|c|c|c|c|c|}
\hline \multirow[t]{3}{*}{ Masa Kerja } & \multicolumn{4}{|c|}{ Keluhan Kelelahan Mata } & \multirow{2}{*}{\multicolumn{2}{|c|}{ Jumlah }} \\
\hline & \multicolumn{2}{|c|}{ Tidak Ada } & \multicolumn{2}{|c|}{ Ada } & & \\
\hline & $\mathrm{n}$ & $\%$ & $\mathrm{n}$ & $\%$ & $\mathrm{n}$ & $\%$ \\
\hline 1-5 Tahun & 6 & 10,9 & 5 & 9,1 & 11 & 100,0 \\
\hline 6-10 Tahun & 2 & 3,6 & 9 & 16,4 & 11 & 100,0 \\
\hline$>10$ Tahun & 1 & 1,8 & 32 & 58,2 & 23 & 100,0 \\
\hline Jumlah & 9 & 16,4 & 46 & 83,6 & 55 & 100,0 \\
\hline
\end{tabular}


Berdasarkan Tabel 11, diketahui bahwa sebanyak 32 pekerja $(58,2 \%)$ yang memiliki masa kerja > 10 tahun mengalami kelelahan mata. Hasil uji statistika fisher exact yang telah dilakukan menunjukkan nilai kontingensi sebesar 0,475. Hubungan masa kerja pekerja dengan keluhan kelelahan mata adalah memiliki hubungan yang cukup kuat. Dapat disimpulkan bahwa pekerja yang memiliki masa kerja yang lama, memiliki risiko tinggi tinggi terhadap terjadinya kelelahan mata.

Masa kerja memiliki hubungan dengan keluhan kelelahan mata. Menurut Suma'mur
(2014) masa kerja merupakan faktor yang memengaruhi keluhan kelelahan mata karena semakin lama tenaga kerja bekerja akan mengakibatkan ketrampilan tenaga kerja meningkat sehingga tenaga kerja dalam menyelesaikan pekerjaannya akan lebih cepat ${ }^{11}$. Hal ini akan memperpendek waktu mata berakomodasi untuk melihat objek kerja. Menurut Syaifuddin (2011) masa kerja dari seseorang yang bekerja dapat menyebabkan kelelahan mata ${ }^{1}$. Terutama jika penerangan di ruang kerja tidak memadai atau tidak memenuhi syarat yang telah ditetapkan.

\section{Hubungan Lama Kerja Pekerja dengan Keluhan Kelelahan Mata}

Tabel 12. Hubungan Lama Kerja Pekerja dengan Keluhan Kelelahan Mata pada Pekerja di Bagian Produksi Penjahit Bordir CV "X" Bangil, Pasuruan Tahun 2018

\begin{tabular}{|c|c|c|c|c|c|c|}
\hline \multirow[t]{3}{*}{ Lama Kerja } & \multicolumn{4}{|c|}{ Keluhan Kelelahan Mata } & \multirow{2}{*}{\multicolumn{2}{|c|}{ Jumlah }} \\
\hline & \multicolumn{2}{|c|}{ Tidak Ada } & \multicolumn{2}{|c|}{ Ada } & & \\
\hline & $\mathrm{n}$ & $\%$ & $\mathrm{n}$ & $\%$ & $\mathrm{n}$ & $\%$ \\
\hline 4-8 Jam & 8 & 14,5 & 14 & 25,5 & 22 & 100,0 \\
\hline$>8 \mathrm{Jam}$ & 1 & 1,8 & 32 & 58,2 & 33 & 100,0 \\
\hline Jumlah & 9 & 16,4 & 46 & 83,6 & 55 & 100,0 \\
\hline
\end{tabular}

Berdasarkan Tabel 12, diketahui bahwa sebanyak 32 pekerja $(58,2 \%)$ yang memiliki lama kerja > 8 jam mengalami kelelahan mata. Hasil uji fisher exact menunjukkan nilai kontingensi sebesar 0,404, artinya hubungan lama kerja pekerja dengan keluhan kelelahan mata adalah memiliki hubungan yang cukup kuat. Sehingga dapat disimpulkan bahwa semakin lama bekerja melampaui batas yang dianjurkan maka semakin tinggi pula risiko terjadinya kelelahan mata.
Masa kerja dapat memiliki hubungan dengan keluhan kelelahan mata. Menurut Tarwaka (2015) dengan memperpanjang waktu kerja lebih dari 8 jam kerja yang telah ditetapkan akan menurunkan efisiensi kerja, meningkatkan kelelahan kerja, penyakit akibat kerja, dan kecelakaan di tempat kerja. Sedangkan menurut Sucipto (2014) lama kerja dari seseorang yang bekerja dapat menyebabkan kelelahan mata, terutama jika penerangan di ruang kerja tidak memadai atau tidak memenuhi syarat ${ }^{12}$. 


\section{Hubungan Kelainan Refraksi Pekerja dengan Keluhan Kelelahan Mata}

Tabel 13. Hubungan Kelainan Refraksi Pekerja dengan Keluhan Kelelahan Mata pada Pekerja di Bagian Produksi Penjahit Bordir CV "X" Bangil, Pasuruan Tahun 2018

\begin{tabular}{cccccccc}
\hline \multirow{2}{*}{ Kelainan Refraksi } & \multicolumn{3}{c}{ Keluhan Kelelahan Mata } & \multicolumn{2}{c}{ Jumlah } \\
\cline { 2 - 6 } & \multicolumn{2}{c}{ Tidak Ada } & \multicolumn{2}{c}{ Ada } & \multicolumn{2}{c}{} \\
\cline { 2 - 6 } & $\mathrm{n}$ & $\%$ & $\mathrm{n}$ & $\%$ & $\mathrm{n}$ & $\%$ \\
\hline Tidak & 8 & 14,5 & 12 & 21,8 & 22 & 100,0 \\
Ya & 1 & 1,8 & 34 & 61,8 & 35 & 100,0 \\
\hline Jumlah & 9 & 16,4 & 46 & 83,6 & 55 & 100,0 \\
\hline
\end{tabular}

Berdasarkan Tabel 13, diketahui bahwa sebanyak 34 pekerja $(61,8 \%)$ yang mengalami kelainan refraksi mata juga mengalami kelelahan mata. Hasil uji statistika fisher exact yang telah dilakukan menunjukkan nilai kontingensi sebesar 0,435. Hubungan kelainan refraksi (pemakaian kacamata) pada pekerja dengan keluhan kelelahan mata adalah memiliki hubungan yang cukup kuat. Sehingga dapat disimpulkan bahwa pekerja yang mengalami kelainan refraksi atau menggunakan kacamata pada saat bekerja, memiliki risiko yang lebih tinggi terhadap terjadinya kelelahan mata.

Menurut Syaifuddin (2011) kelainan refraksi yang dimiliki seseorang ini biasanya menyebabkan mata akan lebih cepat untuk mengalami kelelahan mata ${ }^{1}$. Selain itu, adanya penerangan yang tidak memadai juga dapat memicu terjadinya kelainan refraksi mata pada pekerja yang pada awalnya tidak mengalami kelainan refraksi mata.

\section{Hubungan Kebiasaan Merokok Pekerja Dengan Keluhan Kelelahan Mata}

Tabel 14. Hubungan Kebiasaan Merokok Pekerja dengan Keluhan Kelelahan Mata pada Pekerja di Bagian Produksi Penjahit Bordir CV "X” Bangil, Pasuruan Tahun 2018

\begin{tabular}{|c|c|c|c|c|c|c|}
\hline \multirow[t]{3}{*}{ Kebiasaan Merokok } & \multicolumn{4}{|c|}{ Keluhan Kelelahan Mata } & \multicolumn{2}{|c|}{ Jumlah } \\
\hline & \multicolumn{2}{|c|}{ Tidak Ada } & \multicolumn{2}{|c|}{ Ada } & & \\
\hline & $\mathrm{n}$ & $\%$ & $\mathrm{n}$ & $\%$ & $\mathrm{n}$ & $\%$ \\
\hline Tidak & 8 & 14,5 & 9 & 16,4 & 17 & 100,0 \\
\hline Ya & 1 & 1,8 & 37 & 67,3 & 38 & 100,0 \\
\hline Jumlah & 9 & 16,4 & 46 & 83,6 & 55 & 100,0 \\
\hline
\end{tabular}

Berdasarkan Tabel 14, diketahui bahwa sebanyak 37 pekerja $(67,3 \%)$ yang memiliki kebiasaan merokok juga mengalami kelelahan mata. Hasil uji fisher exact menunjukkan nilai kontingensi sebesar 0,485. Hubungan kebiasaan merokok pekerja dengan keluhan kelelahan mata adalah memiliki hubungan yang cukup kuat. Dapat disimpulkan pekerja yang memiliki kebiasaan merokok saat bekerja, memiliki risiko tinggi terhadap terjadinya kelelahan mata. 
Menurut Triwanto (2007) Semakin lama dan tinggi frekuensi merokok, semakin tinggi pula tingkat keluhan otot yang dirasakan. Hal ini sebenarnya terkait erat dengan kondisi kesehatan mata seseorang ${ }^{13}$. Akibat dari asap rokok yang mengandung banyak senyawa racun aktif berbahaya seperti tar, hidrokarbon aromatik polisiklik, formaldehida, karbon monoksida, dan logam berat. Senyawa aktif tersebut dapat meningkatkan degenerasi makula dengan mengganggu aliran darah ke retina dan melalui proses oksidasi. Kebiasaan merokok berisiko jauh lebih besar hingga 2 sampai dengan 4 kali lebih besar dari orang-orang yang tidak pernah merokok.

\section{SIMPULAN DAN SARAN}

\section{Simpulan}

Intensitas penerangan di bagian produksi Penjahit Bordir CV "X” Bangil Pasuruan belum ada yang memenuhi standar penerangan yang dianjurkan oleh Peraturan Menteri Kesehatan Nomor 70 Tahun 2016. Keadaan kualitas penerangan ditunjukkan dengan adanya pekerja yang menganggap kesilauan, gangguan bayangan dan gangguan ketidaksesuaian dekorasi ruangan.

Sebagian besar usia pekerja adalah $>40$ tahun, paling banyak pekerja memiliki masa kerja selama lebih dari 10 tahun. Sebagian besar pekerja juga memiliki lama kerja > 8 jam dalam sehari. Selain itu, sebagian besar pekerja memiliki kelainan refraksi atau penggunaan kaca mata dan juga memiliki kebiasaan merokok.

Sebagian besar pekerja mengalami keluhan kelelahan mata. Keluhan mata tersebut berupa iritasi mata, penglihatan ganda, ketajaman menurun, fokus mata berkurang hingga sakit kepala. Intensitas penerangan memiliki hubungan signifikan dengan kelelahan mata pekerja. Begitu pula dengan kualitas penerangan yaitu kesilauan, bayangan dan dekorasi ruangan juga memiliki hubungan yang signifikan dengan kelelahan mata pekerja.

Karakteristik pekerja yang meliputi usia, masa kerja, lama kerja, kelainan refraksi (penggunaan kaca mata) dan kebiasaan merokok memiliki hubungan yang signifikan dengan kelelahan mata pekerja.

\section{Saran}

CV "X" perlu untuk membuat jadwal pemeliharaan dan pembersihan lampu, armatur, jendela dinding, lantai dan meja kerja. Selain itu, perlu meningkatkan intensitas penerangan di tempat kerja.

\section{REFERENSI}

1. Soeripto M. Higiene Industri. Jakarta: Balai FK Universitas Indonesia; 2008.

2. Syaifuddin. Anatomi Fisiologi Kurikulum Berbasis Kompetensi untuk Keperawatan dan Kebidanan Edisi 4. Jakarta: EGC; 2011.

3. Febriana S. Faktor-faktor yang berkaitan dengan Kelelahan Mata pada Karyawan Bagian Administrasi di PT. Indonesia Power UBP Semarang. 2012;1(2). Available from: http://ejournals1.undip.ac.id/index.php/jkm 
4. Hikmatyar. Analisis Faktor-faktor terhadap Kejadian Computer Vision Syndrome (CVS) pada Pekerja Layout Editor di CV.X Tembalang Kota Semarang. 2012; Available from: http://eprints.undip.ac.id/38002/1/4447.pdf

5. Hiola R. Sistem Pencahayaan pada Pengeraji Karawo Gorontalo. Gorontalo: Lautikabooks; 2000.

6. Permenkes RI. Peraturan Menteri Kesehatan Republik Indonesia Nomor 70 Tahun 2016 Tentang Kesehatan Lingkungan Kerja Industri. 2016;

7. Ganong WF. Buku Ajar Fisiologi Kedokteran. Jakarta: EGC; 2009.

8. Grandjean E. Fitting The Task to The Man. A Text book of Occupational Ergonomics, 4 th edition. London; 1998.

9. Tarwaka. Ergonomi Industri atau DasarDasar Pengetahuan Ergonomi dan Aplikasi di Tempat Kerja. Surakarta: Harapan Press; 2015.

10. Anizar. Teknik Keselamatan dan Kesehatan di Industri. Medan: Graha Ilmu; 2009.

11. Suma'mur P. Higiene Perusahaan dan Kesehatan Kerja (Hiperkes). Jakarta: Sagung Seto; 2014.

12. Sucipto C. Keselamatan dan Kesehatan Kerja. Yogyakarta: Gosyen Publishing; 2014.

13. Triwanto S. Stop Merokok. Yogyakarta: Progresif Books; 2007. 